\title{
Conceptualizing Employer-Based Brand Equity and Employer Brand Pyramid
}

\author{
Neerja Kashive (Assistance Professor) \\ VES's Institute of Management Studies and Research \\ Near Municipal School, Collector's Colony, Chembur, Mumbai, India \\ Dr Vandana Tandon Khanna (Associate Professor) \\ K.J Somaiya Institute of management studies \& Research \\ Vidyanagar vidyavihar, Mumbai, India
}

Doi: 10.19044/esj.2017.v13n34p211 URL:http://dx.doi.org/10.19044/esj.2017.v13n34p211

\begin{abstract}
Employer branding is referred to as a firm's efforts to promote, both within and outside the firm, a clear view of what makes it different and desirable as an employer. It constitutes an important concept in today's knowledge intensive contexts where attracting employees with superior skills and knowledge comprises a primary source of competitive advantage. This research paper will focus on building employer brand equity by exploring the previous research on employer brand. Based on the Keller brand pyramid this is an attempt to build similar pyramid for employer brand and see if same concepts of customer based brand equity can be used to conceptualize the idea of employer based brand equity. This will help the organizations to understand the ways to build strong employer brand to attract and retain better talent in their organizations.
\end{abstract}

Keywords : Customer based brand equity, Brand pyramid, Employer Branding, Employer Brand equity, internal branding, Brand endorsement, Brand allegiance, Brand citizenship Behaviour

\section{Introduction}

Organisations have to make extra efforts to maintain their image before the prospective applicants as an attractive employer (Bergeron, 2001). When a firm reaches a higher level of external recognition by developing an employer brand, it becomes much easier for it to attract new talent (Bouchikhi and Kimberly, 2008). Thus employer brand is an effective tool for effective recruitment, employee engagement and retention (Barrow and Mosley, 2005). It is considered to benefit both individuals as well as organisation (Bergeron, 2001). It provides a coherent framework for 
management to simplify and focus priorities, increase productivity and improve recruitment, retention and commitment (Keefe, 2007; Ambler and Barrow, 1996; Backhaus and Tikoo, 2004).

From the employees' point of view, being a member of an organisation having a strong employer brand enhances their self-esteem and strengthens their organisational identification (Lievens et al., 2007). Constant delivery of the brand promise leads to trust and loyalty ensuring a steady supply of applicants (Holliday, 1997) and maintains high commitment and high performance among employees and ultimately organisational effectiveness by promoting the organisation's credibility with employees (Burack et al., 1994). It attracts the right kind of candidates with the culture fit and at the same time gives the prospective employees an assurance of the work experience as expected by them (Bhatnagar and Srivastava, 2008).Employer branding communicates the unique employment proposition of the organisation to prospective hires, current employees and society at large by creating, both within and outside the organisation, an image of the organisation as a distinct and desirable employer (Ambler and Barrow, 1996; Backhaus and Tikoo, 2004; Balmer and Greyser, 2002) and as a good place to work (Bergeron, 2001). This helps differentiate organisations from their competitors by creating a distinct image of the total employment relationship and employee life cycle management which the organisation offers to its prospective and current employees, even when they cannot compete in terms of location or wages (Ployhart,2006).

\section{Literature Review}

\section{Customer-based brand equity}

Customer-based brand equity refers to beliefs held by individual consumers about a product's or a service's brand that affect their preferences and purchasing decisions relative to other unbranded products or services with similar attributes (Aaker, 1991, 1996; Keller, 1993). Such brand equity plays a crucial role in consumers' decisions by (a) increasing the chances that the branded product or service will be among those considered,(b) generating positive affect toward the branded product or service, and (c)creating points of differentiation and reasons to choose the brand over its competitors (Aaker, 1996; Keller, 1993).

Keller(1998) proposed that brand knowledge comprises of brand awareness and brand image. Brand awareness has two important criteria as how fast you can recall a brand and do you recognize the brand. Brand image leads to associations which can be identified by types, favourability, strength and uniqueness. Further association are divided into attributes (product related and on-product related), benefits (economic, functional and symbolic) and attitudes. The non-product related attributes can be classified as price, 
usage image, brand personality and feeling\& experience as shown in figure 1 .

Customer-based brand equity (Aaker, 1991;Keller, 1993) indicates that by creating a unique, favorable brand image in consumers' minds, organizations can increase the likelihood that their products or services will be chosen over similar products or services. Keller (2001) has given four important steps in building strong brand:1) Establish a proper brand identity2) Create an appropriate brand meaning 3) Provide right brand response 4) Evoke Brand relationship as depicted in figure 2.

Figure1: Brand Knowledge Keller(1998)

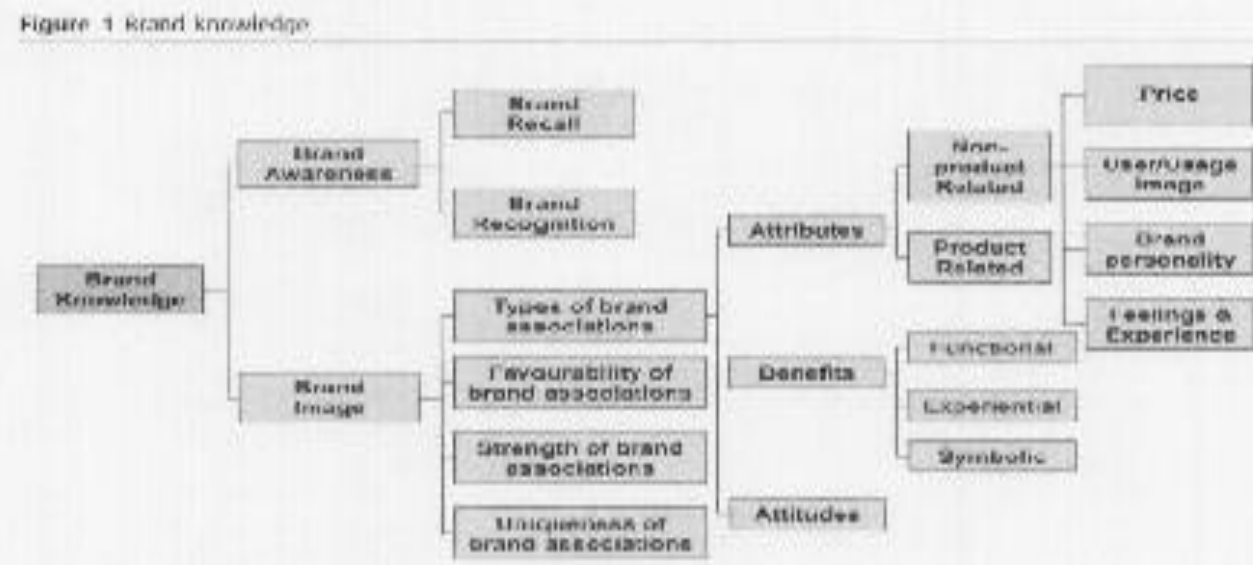

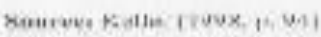

Figure 2: Keller (2001) Customer-based Brand equity pyramid

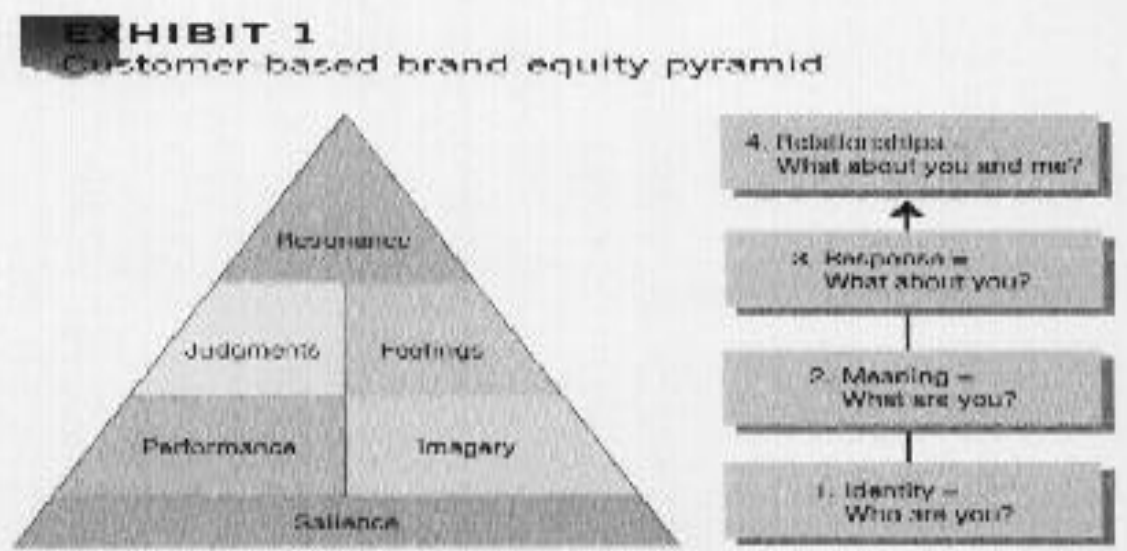

\section{Employer Based Brand Equity}

Cable and Turban (2001) have argued that similar processes may affect job seekers' decisions during recruitments so that organizations with strong brand identities would be preferred to those with weak or negative brand identities. Cable and Turban (2001) proposed that the 
brand equity concept can be generalized to recruitment contexts in which job seekers confront issues similar to those faced by consumers. As consumers do with products and services, job seekers form beliefs about potential employers; these beliefs provide the basis for decisions about whether to pursue or accept employment offers (Barber,1998). Cable and Turban (2001) define employer knowledge as a job seeker's memories and associations regarding an organization as a (potential) employer. Employer knowledge provides applicants with a template to categorize, store, and recall employer-related information. Various researchers have defined employer branding and employer brand equity as given in table 1 .

Table 1 : Contribution of various researcher on Employer Brand and Equity

\begin{tabular}{|c|c|}
\hline Author & Definition \\
\hline $\begin{array}{c}\text { Ambler and } \\
\text { Barrow(1996:p.187) }\end{array}$ & $\begin{array}{c}\text { Defined Employer Branding as "The package of functional, } \\
\text { economical and psychological benefits provided by employment and } \\
\text { identified with the employing company". }\end{array}$ \\
\hline Cable and Turban (2001) & $\begin{array}{l}\text { Employer branding has emerged as a result of the application of the } \\
\text { marketing principles to human resource management especially } \\
\text { recruitment. }\end{array}$ \\
\hline Cable and Turban (2001) & $\begin{array}{c}\text { Defined employer knowledge as a job seeker's memories and } \\
\text { associations regarding an organization as a (potential) employer. } \\
\text { They differentiate between three broad dimensions of employer } \\
\text { knowledge: employer familiarity, employer image, and employer } \\
\text { reputation. }\end{array}$ \\
\hline Mayo (2001) & $\begin{array}{l}\text { Defined employer brand as 'It is what is communicated-consciously } \\
\text { or unconsciously - to every employee or prospective employee.' }\end{array}$ \\
\hline Ewing, et al (2002, p. 14) & $\begin{array}{l}\text { Employment brand equity as "a set of employment brand assets } \\
\text { linked to an employment brand, its name and symbol that add to (or } \\
\text { subtract from) the value provided by an organisation to the } \\
\text { organisation's employees". }\end{array}$ \\
\hline Collins and Stevens (2002) & $\begin{array}{l}\text { Identified two dimensions of employment brand equity: awareness } \\
\text { and associations. }\end{array}$ \\
\hline Lloyd(2002) & $\begin{array}{l}\text { Defined as"Sum of a company's efforts to communicate to existing } \\
\text { and prospective staff that it is a desirable place to work". }\end{array}$ \\
\hline Lievens \& Highhouse( 2003) & $\begin{array}{c}\text { Employer brand consist of instrumental and symbolic aspect of } \\
\text { image. }\end{array}$ \\
\hline $\begin{array}{l}\text { Slaughter, Zickar, Highhouse, } \\
\text { \& Mohr (2004) }\end{array}$ & $\begin{array}{l}\text { Organization personalities as the set of human personality } \\
\text { characteristics perceived to be associated with an organization. }\end{array}$ \\
\hline Martin et al.(2005) & $\begin{array}{l}\text { The strength of the employer branding concept is that it strives to } \\
\text { harmonize internal beliefs with the external brand message. }\end{array}$ \\
\hline Berthon et al. (2005) & $\begin{array}{l}\text { Employer branding as the "sum of a company's efforts to } \\
\text { communicate to existing and prospective staff that it is a desirable } \\
\text { place and 'employer attractiveness' as the envisioned benefits that a } \\
\text { potential employee sees in working for a specific organisation. }\end{array}$ \\
\hline Walker (2006) & $\begin{array}{l}\text { Defined employer brand as 'a set of attributes that make an } \\
\text { organization distinctive and attractive to those people who will feel } \\
\text { an affinity with it and deliver their best performance within it'. }\end{array}$ \\
\hline
\end{tabular}




\begin{tabular}{|c|c|}
\hline $\begin{array}{l}\text { Knox and Freeman } \\
\text { (2006:p 697) }\end{array}$ & $\begin{array}{c}\text { "Image associated with an organization, uniquely in its role as an } \\
\text { employer." }\end{array}$ \\
\hline Lievens et al. (2007) & $\begin{array}{l}\text { "Employer branding is a specific form of managing corporate } \\
\text { identities by creating both within and outside the firm an image of the } \\
\text { firm as a distinct and desirable employer". }\end{array}$ \\
\hline Mosley( 2007) & $\begin{array}{l}\text { The employer brand propositions should be established to ensure that } \\
\text { the rational and emotional benefits are congruent with existing and } \\
\text { potential employees' expectations. }\end{array}$ \\
\hline Moroko and Uncles (2008) & $\begin{array}{l}\text { Employer brand can be regarded as a psychological contract between } \\
\text { an employer and employee and that brand has to be noticeable, } \\
\text { relevant and resonant, and unique. }\end{array}$ \\
\hline Minchington, (2008) & $\begin{array}{c}\text { Defining, creating and managing the organization's employer brand } \\
\text { requires communication expertise. }\end{array}$ \\
\hline Branders (2009) & $\begin{array}{l}\text { Employer branding is an "ongoing process", it focuses "not just on } \\
\text { staff recruitment and retention" but "has a positive effect on } \\
\text { corporate culture and employee motivation, corporate brand } \\
\text { positioning", in other words, on company success. }\end{array}$ \\
\hline $\begin{array}{c}\text { Kimpakorn and Tocquer } \\
\text { (2009:p.534) }\end{array}$ & $\begin{array}{c}\text { "An organization's image as seen through the eyes of its actual and } \\
\text { potential employees." }\end{array}$ \\
\hline Tuzuner and Yuksel (2009) & $\begin{array}{c}\text { Found that potential employees' perception about employer } \\
\text { attractiveness differentiated on the basis of gender }\end{array}$ \\
\hline Van Mossevelde (2010) & $\begin{array}{l}\text { Generally, companies with a good employer brand draw more } \\
\text { applicants, regardless of wage levels, and can even pay a lower salary } \\
\text { than firms with weaker employer brands do for the same position. }\end{array}$ \\
\hline Minchington 2010) & $\begin{array}{c}\text { Employer Branding is a business philosophy in which all functions } \\
\text { have a role to play. }\end{array}$ \\
\hline Jiang and Iles (2011) & $\begin{array}{c}\text { Defined Value propositions or employee-based brand equity in terms } \\
\text { of economic value, social value, development value, interest value, } \\
\text { and brand trust. }\end{array}$ \\
\hline Love and Singh (2011) & $\begin{array}{l}\text { The employer brand helps to communicate what it is like to work for } \\
\text { that specific organization and what the organization represents; it is a } \\
\text { unique value proposition to potential and current employees. }\end{array}$ \\
\hline Schlager et al. (2011) & $\begin{array}{l}\text { EB positively influences company profitability through increased } \\
\text { employee satisfaction, employee identification with the company. }\end{array}$ \\
\hline Priyadarshi, 2011 & $\begin{array}{c}\text { The strong employer brand image is predictor of organizational } \\
\text { outcomes like employee satisfaction, affective commitment and } \\
\text { turnover }\end{array}$ \\
\hline $\begin{array}{l}\text { Kucherov and Zavyalova } \\
\text { (2012) }\end{array}$ & $\begin{array}{l}\text { Identified employer brand attributes into four groups (economic, } \\
\text { psychological, functional and organizational) each of them } \\
\text { corresponding to different aspects of employer attractiveness. }\end{array}$ \\
\hline Robertson and Khatibi (2013) & $\begin{array}{l}\text { Found a significant relationship between companies having strong } \\
\text { employer brand and productivity of employees. }\end{array}$ \\
\hline Gursoy et al.( 2013) & $\begin{array}{l}\text { Age or other demographic variables also shows significant roles in } \\
\text { value preferences. }\end{array}$ \\
\hline Storsten and Ampuero (2013) & $\begin{array}{c}\text { Highlighted that employees' positive perception of employer } \\
\text { branding will make them care more about their employer and will } \\
\text { also aid in employee satisfaction. }\end{array}$ \\
\hline Hillebrandt and Ivens (2013) & $\begin{array}{l}\text { Found work life balance (WLB) as one of the factors affecting } \\
\text { employer brand of the organization. }\end{array}$ \\
\hline Mencl and Lester (2014) & $\begin{array}{c}\text { In their studies differences emerged regarding career advancement } \\
\text { opportunities, diversity climate, and immediate recognition and } \\
\text { feedback, which were more valued by Generation Y. }\end{array}$ \\
\hline
\end{tabular}




\begin{tabular}{|c|c|}
\hline Biswas and Suar(2014) & $\begin{array}{l}\text { Increased realistic job previews, perceived organizational support, } \\
\text { equity in reward administration, perceived organizational prestige, } \\
\text { organizational trust, and leadership of top management, } \\
\text { psychological contract obligation, and corporate social responsibility } \\
\text { increased EB. }\end{array}$ \\
\hline Mathew, 2015 & $\begin{array}{l}\text { Building and communicating the employer brand image among } \\
\text { potential and existing employees is a key concern for the } \\
\text { organizations and also forms a part of their talent strategy }\end{array}$ \\
\hline $\begin{array}{l}\text { Tanwar. K. and Prasad. A. } \\
\text { (2016) }\end{array}$ & $\begin{array}{l}\text { Showed positive relationship between outcomes of employer } \\
\text { branding (job satisfaction and psychological contract) and employee } \\
\text { retention. Positive relationship was found between employer } \\
\text { branding and organizational commitment which in turn contributed } \\
\text { towards development of brand advocacy. }\end{array}$ \\
\hline $\begin{array}{l}\text { Kashyap.V. and Rangnekar.S. } \\
\text { (2016) }\end{array}$ & $\begin{array}{c}\text { Investigated the interrelationships among employer brand perception } \\
\text { (EBP), trust in leaders (TRT) and turnover intentions (TI). The } \\
\text { findings of the study showed that that EBP and subordinate's TRT } \\
\text { were negatively associated with TI. }\end{array}$ \\
\hline
\end{tabular}

Table 2: Conceptualizing Employer Brand Pyramid based on Keller (2001) Customer -based Brand Pyramid

\begin{tabular}{|c|c|c|c|}
\hline $\begin{array}{l}\text { Employer } \\
\text { brand } \\
\text { identity }\end{array}$ & $\begin{array}{l}\text { Employer Brand } \\
\text { awareness }\end{array}$ & $\begin{array}{lc}\text { Cable \& } & \text { Turban( } \\
\text { 2001) } & \\
\text { Collins } & \& \\
\text { Stevens( } & \text { 2002) }\end{array}$ & $\begin{array}{l}\text { Job seekers' awareness of or ability to } \\
\text { identify a company as a potential } \\
\text { employer. } \\
\text { The level of familiarity that job seekers } \\
\text { hold regarding an organization. }\end{array}$ \\
\hline $\begin{array}{l}\text { Employer } \\
\text { brand } \\
\text { Meaning }\end{array}$ & $\begin{array}{l}\text { Functional } \\
\text { associations }\end{array}$ & $\begin{array}{l}\text { Ambler and } \\
\text { Barrow (1996) } \\
\text { Cable and Turban } \\
\text { (2001) } \\
\text { Collins and } \\
\text { Stevens (2002) } \\
\text { Lievens and } \\
\text { Highhouse (2003) } \\
\text { Aaker (1997) }\end{array}$ & $\begin{array}{l}\text { "The package of functional, } \\
\text { economical and psychological benefits } \\
\text { provided by employment and identified } \\
\text { with the employing company" } \\
\text { Potential applicants havesome } \\
\text { knowledge about the attributes of a } \\
\text { specific job at the organization to } \\
\text { which they might consider applying } \\
\text { (job information). } \\
\text { Perceived attributes as job seekers' beliefs } \\
\text { about specific aspects of the job and work } \\
\text { environment of the organization } \\
\text { As instrumental aspects of the } \\
\text { employment brand that would describe } \\
\text { the "objective, physical and tangible } \\
\text { attributes" of the employment offering. } \\
\text { "A set of human characteristics }\end{array}$ \\
\hline
\end{tabular}

\begin{tabular}{|l|l|l|}
\hline associations & $\begin{array}{l}\text { associated with the brand". } \\
\text { Identified five dimensions for 'brand } \\
\text { personality': Sincerity (eg honest, } \\
\text { cheerful), Competence (eg reliable, } \\
\text { successful), Sophistication (eg charming, } \\
\text { upperclass), Excitement (eg daring, } \\
\text { imaginative)and Ruggedness (eg } \\
\text { masculine, tough). }\end{array}$
\end{tabular}




\begin{tabular}{|c|c|c|c|}
\hline & & $\begin{array}{l}\text { Lievens, Van } \\
\text { Hoye and } \\
\text { Schreurs (2005), } \\
\\
\text { Lievens et al., } \\
2007 \text { p. S48 } \\
\text { Slaughter, Zickar, } \\
\text { Highhouse, \& } \\
\text { Mohr, 2004) } \\
\\
\text { Davies } \\
\text { al(2004) }\end{array}$ & $\begin{array}{l}\text { Five factors of personality as :sincerity } \\
\text { (e.g. honest, sincere), excitement(e.g. } \\
\text { daring, exciting), competence (e.g. } \\
\text { intelligent, technical), prestige (e.g. high } \\
\text { status, highly regarded), and ruggedness } \\
\text { (e.g. tough, rugged). } \\
\text { Symbolic aspects of the organizations } \\
\text { employer brand would help describe the } \\
\text { organization in terms of its "subjective, } \\
\text { abstract and intangible attributes" linked to } \\
\text { the organization's image. } \\
\text { Organization personalities as the set of } \\
\text { human personality characteristics } \\
\text { perceived to be associated with an } \\
\text { organization. } \\
\text { Developed organization personality } \\
\text { perception scales: Boy Scout, } \\
\text { innovativeness, dominance, thrift and } \\
\text { Dtyle. } \\
\text { Developed Corporate character scale: } \\
\text { Agreeableness (honest, } \\
\text { responsible); Competence (reliable, } \\
\text { ambitious); Enterprise(innovative, daring); } \\
\text { Ruthlessness (arrogant, controlling); Chic } \\
\text { (stylish, exclusive); Informality(easy } \\
\text { going) and Machismo (tough). }\end{array}$ \\
\hline $\begin{array}{l}\text { Employer } \\
\text { Brand } \\
\text { Response }\end{array}$ & $\begin{array}{l}\text { Employer brand } \\
\text { attitude or Reputation } \\
\text { Feelings(organization } \\
\text { attractiveness }\end{array}$ & $\begin{array}{l}\text { Cable and Turban } \\
\text { (2001) } \\
\text { Collins and } \\
\text { Stevans(2002) }\end{array}$ & $\begin{array}{l}\text { Job seekers' beliefs regarding how } \\
\text { other } \\
\text { individuals affectively view the company } \\
\text { as an employer. } \\
\text { As the level of general positive } \\
\text { feelings } \\
\text { that job seekers hold toward an } \\
\text { organization. }\end{array}$ \\
\hline
\end{tabular}

\begin{tabular}{|c|c|c|c|}
\hline $\begin{array}{c}\text { Employer } \\
\text { Brand } \\
\text { Relationship }\end{array}$ & Brand endorsement & Van Hoye (2008) & $\begin{array}{l}\text { Brand commitment, is the psychological } \\
\text { attachment or the feeling of belonging an } \\
\text { employee has towards an organisation. } \\
\text { Brand endorsement can be defined as the } \\
\text { extent to which an employee is willing to } \\
\text { say positive things about the organisation } \\
\text { (brand) and to readily recommend the } \\
\text { organisation (brand) to others. } \\
\text { Recommendation intentions are defined as } \\
\text { the extent to which employees intend to } \\
\text { recommend their organization as an } \\
\text { employer to others. } \\
\text { Employee brand allegiance (or purchase } \\
\text { intentions in a consumer context) is } \\
\text { defined as the future intention of } \\
\text { employees to remain with the organisation } \\
\text { (brand). } \\
\text { An employee s expression of their } \\
\text { intention to stay with the organisation is } \\
\text { reflective of their awareness of the need to }\end{array}$ \\
\hline
\end{tabular}




\begin{tabular}{|l|ll|l} 
Brand citizenship & $\begin{array}{l}\text { Burmann } \\
\text { Behaviour } \\
\text { Zeplin, 2005, p. } \\
\text { 282). } \\
\text { Burmann et } \\
2009) .\end{array}$ & $\begin{array}{l}\text { al, } \\
\text { "The employees' voluntary basis to } \\
\text { project a number of generic employee } \\
\text { behaviors that enhance the brand identity". }\end{array}$ & $\begin{array}{l}\text { Brand consistent behaviour, can be defined } \\
\text { as an employee behaviour that is often non- } \\
\text { prescribed, yet consistent with the brand } \\
\text { values of the organisation. }\end{array}$ \\
\hline
\end{tabular}

\section{Conceptualization of employer Brand Pyramid Brand identity}

Achieving the right brand identity is creating the brand salience which is related to brand awareness. According to $\operatorname{Keller}(2001)$ brand awareness refers to the customers' ability to recall and recognize the brand. Keller(2001) predicts two dimensions of brand awareness as depth and breadth. Depth of brand awareness refer to how easily customer can recall or recognize the brand. Breadth refers to the range of purchase and consumption situations where the brand comes to the mind. Similarly in recruitment context brand knowledge depict the first dimension as employer familiarity or the level of awareness that a job seeker has of an organization (Cable \& Turban, 2001; Collins \& Stevens, 2002). Organization's overall familiarity is related to applicants' perceptions of a company's attractiveness as an employer, with more familiar organizations being perceived as more attractive (Cable \& Graham, 2000; Gatewood, Gowan, \&Lautenschlager, 1993; Turban, 2001;Turban \& Greening, 1997; Brooks, Highhouse, Russell, \& Mohr,2003).

\section{Brand Meaning}

According to Keller (2001) to give meaning to a brand, it is important to create a brand image and establish what the brand is characteristic by and should stand for in customers' minds. Brand meaning broadly can be distinguished in terms of more functional, performance relatedconsiderations to more abstract, imagery-related consideration.

\section{Performance}

Brand performance refer to the way a product or service satisfy customers' more functional needs. It relate to the intrinsic properties of the brand and product or service characteristics. How well does the brand rate on objective assessments of quality? To what extent does the brand satisfy utilitarian, aesthetic, and economic customer needs and wants in the product or service category?

In the recruitment literature, Gatewood et al. (1993) found that the 
employer brand image is a particularly significant predictor of early decisions made by new recruits about their employers. Turban et al (1998) find that employer brand image positively influences both applicant perceptions of recruiter behaviours and post-interview job and organisational attributes. Ambler and Barrow (1996) defined the employer brand in terms of benefits, calling it 'the package of functional, economic and psychological benefits provided by employment, and identified with the employing company'. This definition is consistent with categorizations of brand concepts in the brand management literature (Gardner and Levy, 1955; Katz, 1960; Park, Jaworski and MacInnis, 1986). For instance, Park, Jaworski and MacInnis (1986) divided brands in three categories on the basis of the consumer needs they fulfil: (a) functional needs, (b) symbolic needs, and (c) experiential needs. Functional or instrumental brand benefits describe the product in terms of objective, physical and tangible attributes that a product either has or does not have. These product-related attributes enable consumers to maximize benefits and minimize costs (i.e. consumptionrelated problems).Lievens and Highhouse (2003) refer to job and organizational attributes as instrumental aspects of the employment brand that would describe the "objective, physical and tangible attributes" of the employment offering.

\section{Imagery}

This deals with the extrinsic properties of the product or service which includes how the brand attempts to meet customers' more abstract psychological or social needs.Four category of imagery was suggested by keller(2001):User Profile, Purchase and usage situation, personalities and value as and History, heritage and experience. The brand associations making up the brand meaning can be categorized into three dimansions: 1 . Strength (how strongly the brand is identified with a brand association), 2 . Favourability (how important or valuable the brand association is to customers) and 3, uniqueness(how distinctively the brand is identified with the brand association).

Similarly in employment context employee identification with an organisation is increasingly considered vital for any business, particularly in the context of corporate services brands where employees' attitudes and behaviours could either make or break the brand, Stuart (2002, p. 30).

Symbolic aspects describe the product in terms of subjective, abstract and intangible attributes that accrue from how people perceive a product and make inferences about it rather than what they think a product does or has. Symbolic attributes are linked to people's need to maintain their selfidentity, to enhance their self-image, or to express themselves (their beliefs, their traits and their personality) (Aaker, 1997,1999; Katz, 1960; Shavitt, 
1990).For some years researchers (such as Aaker, 1997) have discussed the idea of organisations having personality characteristics, in particular distinguishing between symbolic and instrumental personality Characteristics. According to Lievens and Highhouse (2003) and Lievens et al. (2007), symbolic aspects of the organisations employer brand would help describe the organisation in terms of its "subjective, abstract and intangible attributes" linked to the organisation's image (Lievens et al., $2007 \mathrm{p}$.

S48). (Lievens \& Highhouse, 2003; Slaughter, Zickar, Highhouse, \& Mohr, 2004) provided an interesting new trait-oriented perspective to employer reputation. These studies reveal that potential applicants reliably and meaningfully ascribe traits to organizations. Lievens and Highhouse(2003) reported that symbolic image dimensions accounted for incremental variance over and above instrumental attributes in predicting a bank's perceived attractiveness as an employer. Slaughter et al. (2004) focused on the symbolic image dimensions and confirmed that they were related to organizational attractiveness. Lievens, Van Hoye and Schreurs (2005) confirmed the incremental variance of symbolic image dimensions over and above instrumental image components in explaining students' attraction.

\section{Brand Response}

According to Keller(2001), the brand should provide favorable response from the customer. Strong favourable and unique brand meanings will create a strong brand response for a particular brand. This include what customer feel or think about a brand. The brand response can be divided into judgment and feelings.

a. Judgement: Brand judgment focus on customers' personal opinion about the brand based on how they have put meaning to the brand with respect to performance and imagery associations. Four types of summary judgment are important to creating strong brand: Quality, Credibility, Consideration and Superiority.

This can be related to Product awareness and employer knowledge even in recruitment context. Product awareness, which is defined as the extent to which job seekers are likely to be familiar with the company's products or services through either direct exposure or advertising efforts, plays an important role in influencing job seekers' application behaviors (Cable \&Turban, 2001).

For example, job seekers are more likely to be familiar with a company as an employer if that company has high visibility through wellknown products or services (Barber, 1998).Job seekers may also begin to develop affective beliefs about the company as an employer through exposure to the company's product advertising (Cable, Aiman-Smith, 
Mulvey, \& Edwards,2000) or through direct exposure to the company's products or services (Barber, 1998). Specifically, product awareness may act to signal the quality and viability of the company as an employer, increasing job seekers' perceptions of employer reputation (Cable\& Turban, 2001; Collins \& Han, 2004).

b. Feelings: How does the brand affect customers' feeling about themselves and their relationship with others? The feeling associated with the brand can be mild, intense, positive or negative. According to Kahle and colleagues the feeling can be divided into more experiential and immediate, increasing the level of intensity like warmth, fun, excitement or more private and enduring, increasing level of gravity like security, social approval and self-respect.

In recruitment context the feelings are in terms of attractiveness of an organization and general reputation in mind of the potential employees.According to Cable and Turner(2001) reputation is the job seekers' beliefs regarding how other individuals affectively view the company as an employer. Collins and Stevans(2002) says the attitude is the level of general positive feelings that job seekers hold toward an organization. A closely related concept to 'employer branding' is the notion of 'employer attractiveness'. This concept has been broadly discussed in the areas of vocational behaviour (Soutar \& Clarke 1983), management (Gatewood et al. 1993), applied psychology (Jurgensen 1978; Collins \&Stevens 2002), communication (Bergstrom et al. 2002) and marketing (Ambler \& Barrow 1996; Gilly \& Wolfinbarger 1998; Ambler 2000; Ewing et al.

2002). Berthon et, al (2005) defined 'employer attractiveness' as the envisioned benefits that a potential employee sees in working for a specific organisation. He further suggest that, the more attractive an employer is perceived to be by potential employees, the stronger that particular organisation's employer brand equity. Many authors have suggested that decisions to apply to an organization are often heavily based on the general impression that applicants hold about the company's overall attractiveness (e.g.. Belt \& Paolillo,1982; Fombrun \& Shanley, 1990; Rynes, 1991).

\section{Brand Relationship}

According to Keller(2001) this relate to level of personal identification a customer has with the brand. It tells the nature of relationship customer has with the brand and are they sync with the brand. It is characterized by the level of psychological bonding shown by customer. Brand relationship is shown through: Behavioral Loyalty, Attitudinal attachment, Sense of community and Active 
engagement. Brand relationship involves two dimensions namely activity and intensity. Intensity involve strength of attitudinal attachment and sense of community. Activity involves how often the customer purchase the brand and how much are they engaged in other activities other than during purchase and consumption.

With respect to employer brand, recommendation intention may be one of the response. Recommendation intentions are defined (Van Hoye, 2008) as the extent to which employees intend to recommend their organization as an employer to others. In organizational psychology literature, viability of organizations is linked to employees' willingness to engage in cooperative behaviors (e.g., Podsakoff, Ahearne, \& McKenzie, 1997).Tyler and Blader (2001) consider behavior that engages individuals in non-required behavior to promote the organization's goals as cooperative. Recommendation intentions could then be considered as cooperative intentions and consequently impact favorably the organization. Thus word of mouth, as a recruitment source, is an important determinant of organizational attractiveness (e.g., Van Hoye, 2012) and has a beneficial impact on post hire outcomes such as job satisfaction, performance and likeliness to quit (Breaugh \& Starke, 2000; Zottoli \&Wanous, 2000). According to Van Hoye, (2012) suggests that credibility is an important determinant of organizational attraction and that experiential sources are perceived as more credible than informational sources. Organizations should enable job seekers to obtain employment information through direct personal experience. The credibility of informational sources such as job advertisements and websites might be enhanced by making them more personal and vivid, like using employee testimonials.

Through their perception of fairness (Deluga, 1994) and support from the organisation (Wayneet al., 1997), employees exhibit behaviours that are beyond the formally articulated requirements of their job (Deluga, 1994; Beckett-Camarata et al., 1998). Such behaviours, identified as brand citizenship behaviour, are employee behaviours that are non-prescribed or "above and beyond the norm", yet consistent with the brand values of the organisation, thus engendering positive organisational outcomes. Burmann et al. (2009) believe that the key determinants of brand strength as a result of internal brand management practices are brand commitment (BC) and brand citizenship behaviours (BCB). Brand commitment, is the psychological attachment or the feeling of belonging an employee has towards an organisation. This perspective of commitment is consistent with the higher order brand resonance that Keller (2001) believes is the pinnacle in external brand building and, essential for the creation of brand equity. 


\section{Brand endorsement}

Employee external promotion / communication of the brand to others, or referrals, is considered to be another equally important aspect of brand supporting behaviour. Brand endorsement can be defined as the extent to which an employee is willing to say positive things about the organisation (brand) and to readily recommend the organisation (brand) to others. Shinnar et al (2004, p. 273) promotes the idea that employees who hold a favourable disposition towards their organisation are intrinsically motivated to partake in positive external communication. Employee activity not only derives benefits for the employee. An employee's personal advocacy also contributes to positive organisational outcomes or such as increased recruitment cost efficiencies ( Morehart, 2001 ), better employee performance ( Kirnan et al , 1989 ) and more pre-employment knowledge ( Williams et al , 1993 ) that subsequently impact on organisational socialisation.

\section{Brand allegiance}

Employee brand allegiance (or purchase intentions in a consumer context) is defined as the future intention of employees to remain with the organisation (brand). This intention is considered to be an important decision, given the significant economic impact attributed to losing knowledgeable employees ( Ramlall, 2004 ). This also helps in developing significant human capital, whereby employees are considered to possess skills experience and knowledge that, in turn, creates economic value for organisations through increased productivity ( Snell and Dean, 1992). Through the retention of productive employees who consistently exhibit brand-related behaviours, service brand success is likely to be enhanced. This is so because the service brand promise is consistently delivered in a cost-effective and efficient manner. According to

Punjaisri and Wilson (2007), an employee' s expression of their intention to stay with the organisation is reflective of their awareness of the need to live up to the brand standards. This future-orientated thinking has been manifested in the theory of reasoned action, which suggests that the best predictor of future behaviour is the intention to act ( Schiffman et al, 2001 ).

\section{Brand citizenship behaviour}

Employees who are satisfied with their work environment tend to exhibit behaviours that are beyond the formally articulated requirements of their job (Beckett-Camarata et al , 1998 ). Such behaviours i.e brand consistent behaviour, can be defined as an employee behaviour that is often non-prescribed, yet consistent with the brand values of the organisation( Burmann et al,2009 ).The significance of brand-supporting behaviour is that 
it is discretionary ( Castroet al , 2005 ), yet considered to be vital for organisational productivity ( Deluga, 1994 ).According to Deluga (1994), this is attributed to the fact that service organisations cannot possibly predict all the appropriate employee behaviours that are required for organisational success. Brand consistent behaviour,or brand citizenship behaviour as coined by Burmann and Zeplin (2005), is considered to be ' the pivotal(behavioural) constituent for successful internal brand management'(Burmann et al ,2009, p. 266 ). Burmann and Zeplin (2005) believe there to be subtle differences with respect to brand-related behaviour in contrast to organisational-related behaviour. They promote a modified perspective to organisational citizenship behaviour (OCB), namely brand citizenship behaviour (BCB). Burmann and Zeplin (2005) believe such a modification is warranted given that OCB is "considered" to have an internal focus while BCB have external focus.

Thus it can be seen from Figure 3, the Employer Brand Pyramid consist of four stages similar to customer-based brand equity pyramid given by keller(2001):

1) Establish employer brand identity as to who are you?

2) Create employer brand meaning as to what are you?

3) Provide right employer brand response as to what do I feel about you?

4) Evoke employer brand relationship as to what connection do we share?

Figure 3: Employer Brand Pyramid (Author's contribution)

\section{Employer Brand Pyramid}

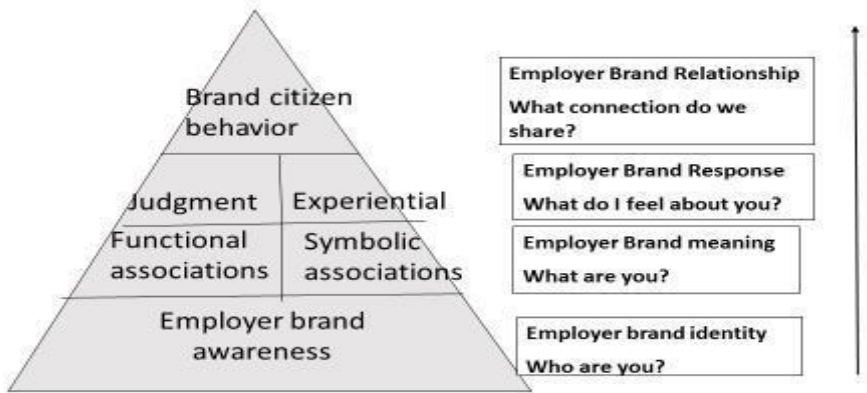

\section{Employer Brand building implications:}

Thus very similar to keller (2001) brand pyramid we can identify and construct employer based brand pyramid. The bottom of pyramid has employer brand familiarity or the awareness as the building block. Awareness has two criteria as the recall of employer name and recognition of 
the brand. Next comes the employer brand meaning which consist of functional and symbolic associations. The functional association talk about the tangible attributes like quality of product sold or the pay, promotion reward, career growth etc. The symbolic associations are linked to personality factors. The next building block of great employer brand is the judgment people have about the organization and feelings attached to it as to do they feel proud to be part of this organization. At the peak of the pyramid is employer brand relationship or resonance as referred by Keller in his pyramid? The strong behavior loyalty is shown to the brand can be created by brand endorsement, brand allegiance and brand commitment. These three factor generate brand citizen behaviour(BCB) which create an intense and active loyalty for the employer brand by the employees.

The above employer brand pyramid will surely help many human resource managers to get the answers for increasing attrition rate, decreasing employee job satisfaction and engagement etc. They will have fairly good idea as to where they need to work upon with respect to communication channels, advertising and promotion strategies. The real application of this concept can only happen when organization apply the complete employer brand pyramid from the bottom to top and take care at every stage that they are moving in right direction.

\section{Limitation and future research}

The above conceptualization of employer brand pyramid do have some shortcomings as to can customer-based brand pyramid can be fully replicated for employer brand pyramid, as their will lot of dissimilarity between product and organization. Buying a product is more short term investment than selecting an organization to work for. The service brand concept can though be more related to employer brand as both talk about internal branding and internal brand management.

The concept of brand dissonance can also be applied to employer brand dissonance as discussed by Berthon et, al (2005). Future research should focus on how the so-called 'employment brand' affects postemployment dissonance. As for product purchases, the brand is used to assure consumers that they have made the right product choice to increase consumer satisfaction and decrease post-purchase dissonance. Similarly, there is a need to determine whether the employer brand can increase job choice satisfaction and decrease post-employment dissonance once an employee become part of the organization. This will lead to better retention and engagement strategy.

The future research can focus majorly on the validation of employer brand pyramid by constructing the scale to measure employer brand equity. The scale will need to collect data from potential employees for employer 
brand awareness and employer brand meaning. They also need to assess current employees on employer brand response and employer brand relationship. How these four stages of employer brand building can be integrated to get the strong employer brand.

\section{Conclusion}

As organisations seek both to attract new employees and retain existing staff, employment advertising and employment branding becomes more and more important. This can be achieved only when organisations understand the factors contributing towards 'employer attractiveness'. When organisations work towards integrating various factors into the employment brand then they can hope to successfully compete globally in attracting new employees. Companies wishing to recruit staff should recognize the type of image they present to potential employees and, if necessary, to present themselves more explicitly to the labor market so as to attract the best match of applicant. There would be little point in attracting the highly introverted to apply to work in an Enterprising organization, unless the organization wishes to change its identity. The right person-organization fit will lead to more loyal employees who can contribute effectively to the organization.

Thus employer need to know very clearly how they want to be known in the external market and what kind of talent are they looking for. Employer are experimenting with newer and newer sources of recruitment and using social media to approach potential employees. It will be a good to identify if these companies have the same image in external market as they want to promote or different. If different they have to work on their employer branding efforts to communicate right image. This will also help in understanding why some organizations are termed as "Employer of choice" and have strong employer brand.

\section{References:}

1. Aaker, D.A. (2004), "Leveraging the corporate brand", California Management Review, Vol. 46 No. 3, pp. 6-18.

2. Ambler T and Barrow S (1996), "The Employer Brand", Journal of Brand management, Vol. 4, No. 3, pp. 185-206.

3. Aurand, T. W ., Gorchels, L . and Bishop, T . R . (2005) 'Human resource management's role in internal branding: An opportunity for cross functional brand message synergy', Journal of Product and Brand Management, Vol. 14 , No. 3 ,pp. $163-169$.

4. Backhaus K and Tikoo S(2004),"Conceptualizing and Researching Employer Branding", Career Development International, Vol. 9, Nos. 4 and 5,pp. 505-510.

5. Berthon, Ewing M J and Hah L L (2005), "Captivating Company: 
Dimensions of Attractiveness in Employer Branding", International Journal of Advertising, Vol. 24, No. 2,pp. 151-172.

6. Biswas, M. \& Suar, D. (2014). Antecedents and consequences of employer branding. Journal of Business Ethics, doi:10.1007/s 10551014-2502-3.

7. Burmann, C and Zeplin, S . (2005 ) Building brand commitment: A behavioural approach to internal brand management. Journal of Brand Management 12 (4) : 279 - 300.

8. Cable, D. M., \& Turban, D. B. (2001). Establishing the dimensions, sources and value of job seekers' employer knowledge during recruitment. In G. R. Ferris (Ed.), Research in personnel and human resources management (pp. 115-163). New York: Elsevier Science.

9. Collins, C.J. \& Stevens, C.K. (2002), "The relationship between early recruitment related activities and the application decisions of new labor-market entrants: a brand equity approach to recruitment." Journal of Applied Psychology, 87(6),pp. 1121-1133.

10. Collins, C.J. and Han, J. (2004), "Exploring applicant pool quantity and quality: the effects of early recruitment practices, corporate advertising, and firm reputation", Personnel Psychology, Vol. 57, pp. 685-717.

11. Davies, G.J., Chun, R., Da Silva, R. and Roper, R. (2004), “A corporate character scale to assess employee and customer views of organisation reputation", Corporate Reputation Review, Vol. 7 No. 2, pp. 125-46.

12. Ewing, M.T., Pitt, L.F., de Bussy, N.M. \& Berthon, P. (2002) Employment branding in the knowledge economy. International Journal of Advertising, 21(1), pp. 3-22.

13. Foster,C. Punjaisri ,K .Cheng,R. 2010), "Exploring the relationship between corporate, internal and employer branding", Journal of Product \& Brand Management,19/6 (2010) 401-409.

14. Hillebrandt, I., \& Ivens, B.S. (2013). Scale development in employer branding. In Impulse für die Markenpraxis und Markenforschung (pp. 65-86). Springer Fachmedien Wiesbaden.

15. Henkel , S ., Tomczak, T ., Heitmann, M . and Herrmann, A . ( 2007 ) Managing brand consistent employee behavior : Relevance and managerial control of behavioural branding. Journal of Product and Brand Management 16 (5) : 310 - 320 .

16. Jiang TT, Iles P (2011) Employer-brand equity, organizational attractiveness and talent management in the Zhejiang private sector, China. J Technol Manag China 6:97-110.

17. Kashyab.V. and Rangnekar. S. (2016), "The Mediating Role of Trust: Investigating the Relationships among Employer Brand 
Perception and Turnover Intentions", Global Business Review,17(3S) 64S-75S. DOI: 10.1177/0972150916631083.

18. Keller, K.L. (1998), Strategic Brand Management: Building, Measuring and Managing Brand Equity, Prentice-Hall, Englewood Cliffs, NJ.

19. Kimpakorn N and Tocquer G (2009), "Employees' Commitment to Brands in the Service Sector: Luxury Hotel Chains in Thailand", Brand Management, Vol. 16,No. 8, pp. 532-544.

20. King , C . and Grace , D . ( 2010 ) Building and measuring employee based brand equity . European Journal of Marketing 44 (7/8) : 938 971 .

21. King , C . and Grace , D . ( 2011 ), “Employee brand equity: Scale development and validation" Journal of Brand Management (2012) 19, 268 - 288.

22. Knox , S . and Freeman , C .(2009), Motivating the employee to "live the brand" : a comparative case study of employer brand attractiveness within the firm," journal of Marketing Management 25 (9/10): 695 - 716

23. Kucherov, D., and Zavyalova, E. (2012), 'HRD practices and talent management in the companies with the employer brand', European Journal of Training and Development, 36, 86-104.

24. Lievens E, Hoye Greet V and Anseep E (2007), "Organizational Identity and Employer Image: Towards a Unifying Framework", British Joumal of MüTuigemiínt, Vol. 18, No. 1, S45-S59.

25. Lloyd, S. (2002) Branding from the inside out. BRW, 24(10), pp. 6466.

26. Love, L.F. and Singh, P. (2011), "Workplace branding: leveraging human resources management practices for competitive advantage through 'best employer' surveys", Journal of Business and Psychology, Vol. 26 No. 2, pp. 175-181.

27. Mathew, A. (2015). Talent management practices in select organizations in India. Global Business Review, 16(1),137-150.

28. Mencl, J., \& Lester, S. (2014). More alike than different: What generations value and how the values affect employee workplace perceptions. Journal of Leadership \& Organizational Studies, 1-16. doi: $10.1177 / 1548051814529825$.

29. Minchington, B. (2008), "What's employer branding without communication?", available at:www.iabc.com / cwb /archive /2008 /0708 /Minchington.htm (accessed 12 October 2011).

30. Minchington, B. (2010), "Perception is reality when attracting and retaining talent”, HR Future,No. 5, pp. 12-13.

31. Moroko L and Uncles M (2008), "Characteristics of Successful 
Employer Brands", Journal of Brand Management, Vol. 16, No. 3, pp. 160-175.

32. Mosley, R.W. (2007), "Customer experience, organisational culture and the employer brand", Brand Management, Vol. 15 No. 2, pp. 123-34.

33. Park, C.W., Jaworski, B.J. and MacInnis, D.J. (1986),"Strategic brand concept-image management", Journal of Marketing, Vol. 50, pp. 135-45.

34. Punjaisri, K. and Wilson, A. (2007), "The role of internal branding in the delivery of employee brand promise", Journal of Brand Management, Vol. 15 No. 1, pp. 57-70.

35. Punjaisri, K., Evanschitzky, H. and Wilson, A. (2009),"Internal branding: an enabler of employees' brand supporting behaviours", Journal of Service Management, Vol. 20 No. 2, pp. 209-26.

36. Priyadarshi, P. (2011) "Employer brand image as predictor of employee satisfaction, affective commitment \& turnover" Indian Journal of Industrial Relations, 46:3, pp. 510-522.

37. Robertson, A., \& Khatibi, A. (2013). The influence of employer branding on productivity-related outcomes of an organization. The IUP Journal of Brand Management, 10(3), 17-32.

38. Storsten, H., \& Ampuero, D. (2013). Who are we? A quantitative study on the employer brand of Lycksele municipality. Retrieved from http://www.divaportal.org/smash/get/diva2:636260/FULLTEXT01.pdf.

39. Tanwar.K. and Prasad.A. (2016), "Exploring the Relationship between Employer Branding and Employee Retention", Global Business Review,17(3S),186S-206S. DOI: 10.1177/0972150916631214.

40. Tuzuner, V. L., \& Yuksel, C. A. (2009). Segmenting potential employees according to firms' employer attractiveness dimensions in the employer branding concept. Journal of Academic Research in Economics, 1(1), 46-61.

41. Van Mossevelde, C. (2010), "Employer branding: five reasons why it matters \& five steps to action", available at: www.employerbrandingtoday.com/uk/2010/03/25/employerbranding-five-reasons-why-it-matters-five-steps-to-action/ (accessed 31 July 2011).

42. Walker, P. (2006). Employer branding: A no-nonsense approach. Retrieved 25 July 2013, from http://www.cipid.co.uk/surveys 